\title{
THE INVISIBLE AND UNDERESTIMATED CONTRIBUTIONS TO CREATIVE ACHIEVEMENTS***
}

Creativity is a highly estimated value and an increasingly present topic in contemporary educational, economic, political and media discourses. It is not only considered as a valuable individual quality but as an important company and states competitive asset too. Nowadays, special attention is accorded to creative industries, as they boost national economies. In short, we are surrounded by references to creativity.

However, emphasizing and promoting creativity and praising creative talents may conceal from us all the "non-creative" human, material and immaterial factors and resources which support and make possible creative accomplishments. In other words, behind each individual or group creative achievement there are those who provide logistics, organizational, financial, research, social, psychological and other kinds of support. Individuals or teams would not be able to develop and realize their innovative ideas and projects without some or more collaborators whose various talents, skills, competencies and work are embedded in the creative processes and results.

The purpose of this paper is not to diminish the outstanding importance of creativeness as an inner special quality, but to present a more comprehensive approach to its manifestation, realization and outcomes. We want to bring to light and acknowledge the invisible and underestimated contributions to creative activities. Although it is good to encourage and promote creativity with all available means, we should avoid turning it into a new imperative, a pressure on each and everyone to demonstrate their creative aptitudes, especially in the educational field. This attitude could provoke feelings of frustration, deficiency and self-depreciation in persons who are not particularly creative but possess other valuable and useful qualities and skills, such as analytical, logical, practical, organizational, administrative, managerial, and others.

Creative achievements as results of highly collaborative processes will be illustrated with the example of creative industries.

Keywords: Creativity, Collaborative Process, Diverse Contributions, Education, Creative industries.

\footnotetext{
* Faculty of Culture and Media, Megatrend University, Serbia, tmilivojevic@megatrend.edu.rs

* Faculty of Culture and Media, Megatrend University, Serbia, ljmanic@megatrend.edu.rs

*** This paper was prepared and presented in English language at the 30th International Scientific Conference on Economic and Social Development, at the Megatrend University in Belgrade, Serbia - 25 \& 26 May 2018.
} 


\section{Introduction}

Creativity is a highly estimated value and an increasingly present topic in contemporary educational, economic, political and media discourses. It is not only considered as a valuable individual quality but as an important company and states competitive asset too. However, emphasizing and promoting creativity and praising creative talents may conceal from us all the "non-creative" human, material and immaterial factors and resources which support and make possible creative accomplishments. In other words, behind each creative individual there are people who provide him/her logistic, organizational, financial, research, social, psychological and other kinds of support. The same applies to teams, larger groups and countries which are recognized for their innovations, creative products and services. The same as talented theatre directors and actors could not realize a play without the help of all the collaborators who operate behind the stage, single subjects or groups would not be able to elaborate and realize their creative ideas and projects without all the contributors who are not qualified as creative.

Talents, skills and competencies of people who contribute to creative processes and results are numerous and various. Affirmative discourses on creativity are certainly needed, especially in the education field, but they could impact negatively on students who do not have a rich imagination and original ideas, but whose other abilities and skills could help others to select, develop and realize their creative ideas. Overemphasizing the value of creativity at the expense of other abilities is not helpful, as it is a quite unbalanced and reductionist view of the whole phenomenon.

The aim of this paper is not to diminish the importance of creativity as an individual inner talent, but to show that creative work is a complex collaborative and context-dependent process. On an individual level, creative work requires some thinking and personal characteristics other than those which are commonly labelled "creative"; and on a group level, it requires the help of all the associates who do not belong to the category of the so-called "creatives". Although we are aware of the irreplaceable role of creative talents, we believe that it is equally important to give due recognition to all the contributors who operate in the shadow and whose different skills, knowledge, dedication and work are embedded in the creative processes and achievements.

\section{Multileveled Approach to Creativity}

The phenomenon of creativity demands a multileveled approach. It can be observed by stuyding: creative products, creative processes, creative personality, the environment which encourages and supports creativity and the possibilities to educate creativity. ${ }^{1}$ Accordingly, the American psychologist Yamamoto (1964)

Milivojević, T. (2011): Psihologija stvaralaštva, Beograd: Megatrend univerzitet, p. 29. 
divided all definitions of creativity into four categories: 1 . Personal features, 2 . Creative processes, 3. Interaction between people and their environment and 4. Creative products as a materialization of ideas. ${ }^{2}$ The complex, multidimensional phenomenon of creativity includes an inextricable combination of personal cognitive, emotional and connotative traits, environmental factors and dynamic interaction of internal and external components. Shortly, creativity is conditioned by a high development of certain internal capabilities and favourable external stimulation and support. Therefore, if we want to achieve a better understanding of creativity, the interest for creative individuals will not suffice. Although priceless, their contribution is only a part of the chain, one phase of the entire creative process. Their accomplishments are inconceivable without the accumulation of previous knowledge, without the intellectual and social environment which stimulated their thought and without the social mechanisms which recognized and spread their innovations. ${ }^{3}$

Nowadays, in the context of the prevailing economistic paradigm, the emphasis shifts from individual to organizational and team creativity. "Modern theories of creativity often deal with processes and systems rather than with gifted individuals, which can be considered as a consequence of abandoning the 'heroic' or individual models of human behaviour in theories of psychology and management...Within the post-fordist economy, the focus has shifted from individual abilities to social and organizational frames in which individuals work: from 'know-how' to 'know-who"' 4

\section{Broad and Narrow Understanding of Creativity}

One of the most interesting debates regarding creativity derives from two different approaches to the meaning and scope of this term: the broad and narrow one. We'll begin with a broad understanding of creativity.

When you type the words "creativity" and "education" into Google, you'll come across variations on titles such as: "Study Shows We Are Born Creative Geniuses But The "Education' System Dumbs Us Down"5 or "Everyone is born creative, but it is educated out of us at school" . The prevalence and high ranking of such

Kvaščev, R. (1976): Psihologija stvaralaštva, Beograd: BIGZ, p. 4.

3 Csikszenmihalyi, M. (2006): La créativité: Psychologie de la découverte et de l'invention, Paris: Robert Laffont, p. 14.

$4 \quad$ Bilton, K. (2010): Menadžment i kreativnost. Beograd: Clio, p. 58.

$5 \quad$ Nascimento, G. (2017): We Are Born Creative Geniuses But The 'Education' System Dumbs Us Down. Retrieved 16.02.2018 from https://anewkindofhuman.com/creative-geniusdivergent-thinking-test/.

$6 \quad$ Meng, T.K. (2016): Everyone is born creative, but it is educated out of us at school. Retrieved 16.02.2018 from https://www.theguardian.com/media-network/2016/may/18/born-creative-educated-out-of-us-school-business. 
titles in search engines indicate that the belief that creativity is an innate potential of each human being is currently widespread. But the theories of some famous psychologists show us that we are not dealing with appealing popular opinions only. For example: Guilford ${ }^{7}$ maintained that there is no essential difference in kind between creative imagination and the creation of a tangible product. Winnicott argued in favor of the broadest possible definition of creativity, according to which a house, painting, haircut, symphony or cooking were equal in kind as they all include creativity. He criticized elitism from the standpoint of creativity defined as a universal force, which he identified with Freud's life instinct - eros. ${ }^{8}$ Abraham Maslow asserted that creativity is a natural potential present in all human beings. According to him, the "The key question isn't 'What fosters creativity?' but 'why in God's name isn't everyone creative?' Where was the human potential lost? How was it crippled? I think therefore a good question might not be why do people create? But why do people not create or innovate? We have got to abandon that sense of amazement in the face of creativity, as if it were a miracle that anybody created anything." Likewise Winnicott, Maslow considered that the healthy or optimal human condition is creativity in all its forms and all domains of life and creation - in perception, behaviour, experiencing, communication, teaching and work..$^{10}$

In a sense, there is a quite obvious argument in favour of a broad understanding of creativity: the human intelligence, which is characterized by plasticity, flexibility, capacity to adapt to change, but also to create changes, new products, processes and situations. In other words, human intelligence is creative in itself thanks to the structural and functional plasticity of the human brain. However, when we move from the general anthropological perspective down to the individual level, differences become apparent. Regardless of many texts stating that creativity can be taught, there is ample evidence for the influence of genetic factors in certain domains of creativity ${ }^{11}$ Although giftedness does not entail necessarily creativity, creators are talented for the area in which they achieve high results. "Creativity has commonly been thought of either as a set of domain - general skills that can be applied broadly like a special kind of intelligence or as a general personality trait that colors a person's approach to any kind of task or problem, but these ways of thinking about creativity are misleading." 12

\footnotetext{
$7 \quad$ Guilford, J.P. (1967): The nature of human intelligence, New York: McGraw-Hill.

$8 \quad$ Winnicott, D. (2005): Playing and Reality (2nd edition), Abingdon: Routledge.

9 Maslov, A. (2004): Psihologija u menadžmentu, Novi Sad: Adižes, p. 39.

10 Maslov, A. (2001): O životnim vrednostima, Beograd: IP „Žarko Albulj“, p. 108.

11 Roeling, M.P, Willemsen, G, Boomsma, D. (2016): Heritability of Working in a Creative Profession. In Y-M. In Hur (ed.). Behav Genet 47 (3), p.298-304.

Retrieved 03. 10. 2017 from https://link.springer.com/content/pdf/10.1007\%2Fs10519-016-9832-0. pdf.

12 Baer, J. (2016): Domain Specificity of Creativity: Theory, Research, and Practice. Retreived 12.03.2018 from: http://www.creativitypost.com/science/domain_specificity_of_creativ-
} 
Beside genetic heritage, there are many other factors whose combination and complex interaction affect creativity and creative results. Having this in mind, the supporters of the narrow approach adopt the definition of creativity as "the ability to realize a product that is both new and adapted to the context..."13 As Eysenck thought that "we had to understand that originality was a necessary, but not sufficient condition for creative work." ${ }^{\prime 4}$ These authors consider that creativity involves the ability to realize a product, and this depends on specific conditions within and outside of a person. "Carl Rogers (1954) maintained that 'there must be something observable, some product of creation' in order for us to talk usefully of a creative process having taken place." ${ }^{\prime 5}$ Mac Kinnon $(1963,1969)$ claimed that beside the originality, creativity includes the power of elaboration, adequate evaluation and realization of the idea ${ }^{16}$. Nicholls (1972) stated that general creativity, such as was advocated by Winnicott, is nothing more than "pseudo-creativity"17.

The previous short review of the broad and narrow definitions of creativity is relevant to our main topic insofar as it draws a distinction between creative potentials and creative achievements. Therefore, the focus is on the traits, abilities, factors and resources which contribute to transform the game of imagination into reality, creative concepts into valuable and useful products. The integration of antithetical traits ${ }^{18}$ in one person, which is needed for creative production, is not a common occurrence. This fact points out to the importance of collaborative (formal or/and informal) processes.

\section{Education and Creativity}

Giftedness, talent and creativity represent the highly valued properties of a modern man, which makes them highly desirable international and national educational goals. ${ }^{19}$ Current debates about creativity place emphasis on right brain

ity_theory_research_and_practice.

13 Lubart, T. (2009): Psychologie de la créativité, Paris: Armand Colin, p. 117.

14 Ryckman, R.M. (2014): Theories of personality, Belmont: Wadsworth Cengage Learning, p. 249.

15 Hicks, M.J. (1991): Problem Solving in Business and Management: Hard, Soft and Creative Approaches, Springer-Science+Business Media, B.V. (eBook), p. 34 .

16 Kvaščev, R. (1976), 5-6.

17 Lubart, T. (2009), 119.

18 Csikszentmihalyi named the conjunction of antithetical traits often present in creative people the "paradoxes of creative personality." They contain contradictory extremes; instead of being an 'individual', each of them is a 'multitude'. As white color contains all the colors of the color spectrum, they combine in themselves a whole range of human possibilities. (2006: 79). He identified and described 10 such paradoxes (Idem., 82-103).

19 Maksić, S. (2015): Darovitost, talenti i kreativnost: od merenja do implicitnih teorija. In G. Maksimović (ed.) (2015): O kreativnosti i umetnosi: savremena psihološka istraživanja (p.

Vol. 16, № 3, 2019: 69-82 
functions, such as holistic perception, imagination, fantasy (divergent thinking), intuition, artistic sensibility, etc., to the detriment of left brain functions, like analytical and logical reasoning (convergent thinking), computational skills, rationality, etc. This is understandable given that modern Western societies and their educational policies have advocated for too long the rational left brain functions.

However, the necessary right brain attributes of creativity, such as originality, vivid imagination, unusual associations, biosociative ${ }^{20}$ capacity, intuitive synthesis, etc., are not enough to erect the creative product. Although divergent thinking is the key constituent for creativity, creative production also requires the ability of convergent thinking. First, there are many different ideas (divergences), and then this line is narrowed down through selection, the thought is focused and specified through a convergent process. "Divergent thinking must necessarily be accompanied by the ability to distinguish a good from a bad idea - which implies convergent thinking" ${ }^{21}$. Contrary to the widespread belief that artists are "divergent" and scientists "convergent", both of these components are necessary for creative breakthroughs in the respective fields. The psychologist Peterson states: "If you are open to new information, new ideas, you better be able to intelligently and carefully edit and choose. If you have 50 ideas, only two or three are likely to be good. You have to be able to discriminate or you'll get swamped."22 Education for creativity should therefore retain something from the traditional system and include the areas of learning and training that develop convergent, analytical, critical, rational, logical and practical abilities. On the basis of these abilities selection, successful realization and application of ideas are made.

Expertise is necessary for creative production in any kind of field, but while not all experts are creative, creators are experts in their field. Expertise that enables creative changes in the appropriate field is achieved through long-term disciplined learning, adoption of rules, attainment and knowledge, and exercising skills from the appropriate field. When studying and teaching creativity, we must not succumb to the tendency of "enriching one side of the creative process, enthusiastic, great insight, illumination... and underestimate... the years of hard work and sweat that follow and are necessary to create something useful out of a great idea." ${ }^{23}$ In the essay Tradition and Individual Talent T.S. Eliot warns that 11-29), Niš: Filozofski fakultet Univerziteta, p. 12.

20 Biosociation of bi+association is a term coined by Hungarian-British author Arthur Koestler in his 1964 book The Act of Creation. It signifies a blending of elements drawn from two previously unrelated patterns of thought into a new pattern. https:// en.wiktionary.org/wiki/bisociation

21 Csikszenmihalyi, M. (2006), 84.

22 Peterson, J. (2003): Low Latent Inhibition Plus High Intelligence Leads To High Creativity? Retreived 14.01.2016 from: http://www.futurepundit.com/archives/cat_brain_creativity. html

23 Maslov, A. (2001), 112. 
originality can exist only as a modification and extension of tradition, and not as a voluntary, individual notion (caprice). Attaining tradition comes through great effort. "In the first place it encompasses a sense of history that undoubtedly is necessary for anyone who wants to be a poet after their twenty-fifth year"24 This means that education for creativity must resist the trends of superficiality, floating attention, fragmentation, and speed coming from new digital media.

Honoring the above intrapersonal features and abilities that are not characterized as creative stricto sensu, but are necessary for creative production, is also important on the interpersonal level, in order to appreciate the contribution of students in whom they predominate over the creative mental qualities (divergence, originality, flexibility, etc.). If creativity is set as superior value in absolute terms, reflected in affirmation and promotion through all social mechanisms, it may happen that we begin to perceive it as a social imperative, a pressure on each and everyone to demonstrate their creative aptitudes. This attitude could provoke feelings of frustration, deficiency and self-depreciation in persons who are not particularly creative, but possess other valuable and useful qualities and skills, such as analytical, logical, practical, technical, organizational, administrative, managerial, and others. Creators need these individuals, because creativity is a "multi-dimensional process, combining different styles of thinking and accepting contradictions and paradoxes... It is very unlikely that the desired combination of abilities will be found in one individual." ${ }^{25}$ Different talents gain special significance in creative teams. "Behind the scene teamwork or partnership is the key to analyzing and understanding creative processes and products." 26

The aforementioned findings and arguments warn us that we should not be foolishly enthusiastic about the belief that creativity can be taught. Under the aforementioned article, "Everyone is born creative, but it is educated out of us at school" ${ }^{27}$ we came across an interesting and grounded remark by a commentator, worth quoting almost entirely: "There are actually some quite valid points scattered through this article's self-serving platitudes; creativity is indeed innate; it can indeed be either encouraged or discouraged - inside and outside of school or workplace; schools do indeed often emphasize regimentation instead of creativity. But that's about it. No, 'creativity' per se cannot be 'taught.' The author is probably confusing 'teaching creativity' with 'encouraging individuality' - but these aren't synonymous. You can't teach people to be more 'themselves' since that entails keeping their individualities from becoming tainted by conformity to norms. It's a negative thing rather than a positive. And, unfortunately (or not!), no: not only is it true that we can't all be Mozart, but contrary to the claim,

24 Eliot, T.S. (2015): Tradicija i individualni talenat. Retreived 8. 07.2015 from http://strane. ba/t-s-eliot-tradicija-i-individualni-talenat/.

25 Bilton, K. (2010), 57.

$26 \quad$ Ibid. 51.

27 Meng, T.K. (2016).

Vol. 16, № 3, 2019: 69-82 
not everyone can sing (at all well), either. Do we really need a greater percentage of 'creative people'? Whether the answer is yes or no, we can't just create them-but we can help find and identify them." ${ }^{28}$

So, let's say that some people do not stand out with creative ideation, but they have talent and skills to recognize, encourage and support creative people and their activities. "In ancient Greece, the water carrier was a symbol of creativity - not because of what he did, but because he encouraged and enabled others to express their creativity... Extraodinary individuals, such as Eric Cantona, are only as good the team they play in. Television cameras show only spectacular blows and lightning breaks, but they would not be possible without the action and passing happening on the rest of the field... But players and fans in the stadium see what the television audience does not, and for them water carriers are true stars of the team. ${ }^{29}$ From determining creativity as an individual process, a more comprehensive approach "leads us to a collective model in which creation is the result of cooperation of talented individuals affiliated with a creative team." 30

\section{Complementary Diversity in Creative Teams}

Challenges facing contemporary society require creativity in all aspects of human activity, so recent theories are less concerned with studying individual creativity, and more with creating conditions for encouraging the process itself and creating teams that can recognize the idea, adapt it, and achieve it. Creative teams thus become the bridge between individual and collective creativity, and a high degree of cooperation and interaction within the team is a condition for the realization of ideas.

Previous beliefs that success of the team is dependent on representatives of different sectors within the organization (production, marketing, sales, legal services), are now replaced with focus on importance of personal attributes combinations of team members. In such teams, the creativity of an individual is no longer a key factor of success, but precisely the choice of members that enables the combination of different abilities, thinking styles and mental processes.

Starting from the fact that creativity requires both divergent and convergent thinking, Michael Kirton (1984) developed the Complementarity Theory according to which it is necessary to combine these obviously different styles of thinking for the success of the team. Researching the teamwork of engineers, he concluded that members of most teams can be described as "innovators" who are devising new concepts and, "adapters" whose task is to develop and transform

\footnotetext{
28 The first comment under the pseudonym Proximityl.

29 Bilton, K. (2010), 50.

${ }^{30} \quad$ Ibid. 57.
} 
ideas into practical applications ${ }^{31}$. The research showed that both are necessary for the success of the team. Although homogeneous teams have easily reached agreement, it turned out that their compliance had a negative impact on creativity - teams that were composed exclusively of "innovators" were often unable to implement the idea, while the teams composed of the "adapters" lacked initiative.

Recent theories emphasize the various types of people necessary for the success of the team. Rei Inamoto, the chief creative officer for AKQA, believes that the successful team, especially in the field of startup projects that require a high level of creativity, needs 3 types of people: Hipster, Hacker, and a Hustler. The Hipster is the one that makes the product cool and fashionable. The term hipster - today generally signifies the affiliation to the subculture, but it is used here to denote a person of independent thinking and attitude, develops imagination and intuition, with a sense of art and beyond the mainstreams that are dominant in society. The Hacker is the one who knows how to actually build the product. This is a person who understands the environment, procedures and technology better than others and is able to materialize a creative idea. The Hustler is the one who finds a way to sell the product to the world. Herein sale does not necessarily mean the realization on the market, but creation of something that is worth and necessary, and could be adopted. Hustler is the one who recognizes the value. ${ }^{32}$

In his book, Nathan Furr talks about "Freaks", "Experts" and "Connectors" as compulsory members of a successful team ${ }^{33}$. The "Freaks" are able to "recognize the invisible", to think outside the box; "Experts", on the basis of expertise and skills, recognize the idea at the beginning, and turn it into value; "Connectors" manage relationships within a group, choose members, create relationships and structures in which they will display the best qualities of all team members.

Regardless of whether we are talking about "divergent" and "convergent" or creative and non-creative members, the emphasis is not on the individual, but on the composition and relationships within the team. The success of the team depends on the selection of members, the perpetuation of the balance between different approaches and ways of thinking, and is conditioned by the nature of the task to be solved. Respecting diversity, exchange, linking to one's achievements and ideas is a fundamental part of the creative process, while focusing on individuality and independence suffocates and suppresses other possibilities.

\section{Ibid. 59.}

32 St. Louis I, Lane J. (2016): Start 'Em Up: Incubating Nextgen Innovators, Centre for Human Capital Policy, Canada West Foundation, p.13. Retrived 30.04.2018 from: http://cwf.ca/ wpcontent/uploads/2016/10/HCP_StartEmUpSHAD_Report_OCT2016_WEB.pdf.

33 Furr, N., Dyer, J. (2014): The Innovator's Method: Bringing the Lean Startup into Your Organization, Harvard Business School Publishing, Boston. 


\section{Creativity in Creative Industries}

Twenty years ago emerged the idea that creativity could be the main driver of economic development. Creativity is not necessarily an economic activity, but it can be if it produces an idea with economic implications or a product that can be traded $^{34}$. Ubiquitous activities based on the creativity and talent of an individual, besides resulting in artistic activities and culturally enriching society, can contribute to its economic well-being ${ }^{35}$. Creativity understood in the broadest sense is thus treated as a factor of production. Creativity is seen as a driver of economic growth and a key strategic resource for increasing competitiveness, an important economic and developmental asset of companies and states. Materialized in works that have aesthetic and symbolic value, in patents and innovations, design and style, creativity not only creates products and services, but also represents the potential for new creativity.

According to the definition published in the 1998 Government's Creative Industries Mapping Document, creative industries comprise all those activities that use individual creativity, skills and talent as an essential resource, and which have the potential to create jobs through generation and exploitation of the intellectual property ${ }^{36}$. The narrow approach defines them as the activities that are involved in the conception of "creative products", while the wider approach includes activities that deal with their mass reproduction, distribution and export. The importance of this sector from the economic and social point of view is remarkable. Creative industries create more than $7 \%$ of gross domestic product in the world, with a growth of $10 \%$ per year. In developed countries, which are the leading industries with the highest annual growth, ranging from 5 to $20 \%$. The contribution of industries based on copyright and related rights is significant for Serbia and their share in GDP is 3.1\% (in comparison this contribution is approximate to the contribution of the financial services sector (3.2\%), education (3.9\%) and production of electricity $(3.3 \%) .{ }^{37}$

Creative industries offer great opportunities for employment of mostly young and educated people, primarily through self-employment. It is unorthodox to consider creative industry a sector (it is comprised of organizations varied by number of employees, economic strength, ownership structure), but there

34 Howkins, J. (2001): The Creative Economy: How people Make Money from Ideas, London: Penguin.

35 One of the themes of the jubilee meeting of economists, Kopaonik business forum, in March 2018 were creative industries, several conferences on this topic were held in Belgrade, and Ana Brnabić, the President of the Government of Serbia, founded the Creative Industries Council.

36 Jovičić, S., Mikić, H. (2006): Kreativne industrije u Srbiji, Beograd: British Council, p. 20.

37 Radulović, B. Popović, D. Aleksić, D.(2014): Studija o ekonomskom doprinosu industrija zasnovanih na autorskom i srodnim pravima u Republici Srbiji, Privredna komora Srbije, Beograd, p. 15. 
are certain common elements in these activities. First of all, innovation and creativity are a basic resource. However, it is precisely in the field of creative industries that it is most evident that the creativity of the individual, innovative ideas and inventions are only a small part of the complex production process ${ }^{38}$. Although based on the individual's abilities, creative processes in these industries are essentially collective. Closing credits at the end of the film, the gratitude of the author at the beginning of the book, only confirm the amount of various specialties that contributed to the birth of a "creative product". These teams, usually gathered around a concrete project, are a network of specialists. However, besides those whose work is undoubtedly creative, there is a network of people whose work is necessary: they provide transport, logistics and support, and legal and financial services. According to the system theory of creativity, a network of critics, sellers, agents, publishers, broadcasters, talent hunters, is as important as those from which the product originated ${ }^{39}$. Most of them are specific type of employees - serial monogamists - they work together, very intensely and under great pressure, and then split up after the project ends in order to re-assemble in a new team. This magnificent example shows us see how important the ability to adapt to new people and the environment actually is. ${ }^{40}$

We emphasized several times that creative processes are formed through a combination of different elements, and that the birth of creative products is the result of teamwork. The contribution of the participants is different and difficult to measure, but the economic effects of the participants in devising a "creative product" are comparable. In developed countries creativity protection area is precisely regulated through lawful protection of copyright. The specificity of this right is that it becomes worth to the owner only if it is alienated. Unfortunately, the analysis showed that in this transaction the owners of the right are in an unfavorable position. When we compare the financial means realized by selling a creative product, we will see that a small part of the cake belongs to the creator. Creation of intellectual property is less profitable than the exploitation of this right. Authors (artists, writers, performers) on the basis of creativity acquire assets that are smaller than funds acquired by mediators that reproduce, distribute and sell their property.

\section{Conclusion}

The purpose of this paper is certainly not to diminish the outstanding importance of individual creativity, because "although the contribution of an individual is not as determinative as it is usually thought, it would equally be wrong to claim that without it there could be innovation and that everyone is

\footnotetext{
38 Bilton, K. (2010), 52.

39 Ibid. 99.

$40 \quad$ Ibid. 63.
} 
equally capable of creating something new." ${ }^{\text {"41 }}$ The purpose is to present a more comprehensive approach to what is needed to come to creative achievements. Wouldn't it be ironical that the decades-long scientific process of de-mystification (but not banalization) of creativity, traditionally understood as the sublime gift of a few exceptionnal individuals, ends in a new mystification of creativeness as an incomparable, self-sufficient virtue, superior to all others?

Emphasizing and promoting creativity and praising creative talents may conceal from us all the apparently "non-creative" human, material and immaterial factors and resources which support and make possible creative accomplishments. In others words, behind each individual or group creative achievement there are those who provide logistic, organizational, financial, research, social, psychological and other kinds of support. Individuals or teams would not be able to develop and realize their innovative ideas and projects without some or more collaborators whose various talents, skills, competencies and work are embedded in the creative processes and results.

The most successful companies are those who develop a pervasive talent mindset and treatment of employees in a differentiated way according to their talents. Talent management is not limited to "high flyers" but to anyone whose abilities represent an added value for the organization ${ }^{42}$, especially regarding its creativity and innovation. The same should be applied in education. Teachers should be sensitive to the diversity of talents and affinities, that is, to appreciate and encourage students who do not stand out with their creative imagination, but who with their specific abilities and skills can significantly contribute to creative production.

\section{Literature}

- Baer, J. (2016): Domain Specificity of Creativity: Theory, Research, and Practice. Retreived 12.03.2018 from: http://www.creativitypost.com/science/domain specificity_of_creativity_theory_research_and_practice.

- Benoist, S., Daviaud, E., Rainsard-Demazeau, C., Torres, E. (2012): Le management des talents: enjeu stratégique ou simple évolution vernaculaire RH? Mémoire d'expertise, Paris : Dauphine université.

- Bilton, K. (2010): Menadžment i kreativnost. Beograd: Clio.

- Csikszenmihalyi, M. (2006): La créativité: Psychologie de la découverte et de l'invention, Paris: Robert Laffont.

- Eliot, T.S. (2015): Tradicija $i$ individualni talenat. Retreived 8.07.2015 from http://strane.ba/t-s-eliot-tradicija-i-individualni-talenat/.

41 Csikszenmihalyi, M. (2006), 67.

42 Benoist, S., Daviaud, E., Rainsard-Demazeau, C., Torres, E. (2012): Le management des talents: enjeu stratégique ou simple évolution vernaculaire $R H$ ? Mémoire d'expertise, Paris : Dauphine université, p. 39. 
- Furr, N., Dyer, J. (2014): The Innovator's Method: Bringing the Lean Startup into Your Organization, Harvard Business School Publishing, Boston.

- Guilford, J.P. (1967): The nature of human intelligence, New York: McGraw-Hill.

- Hicks, M.J. (1991): Problem Solving in Business and Management: Hard, Soft and Creative Approaches, Springer-Science+Business Media, B.V. (eBook).

- Howkins, J. (2001): The Creative Economy: How people Make Money from Ideas, London: Penguin.

- Jovičić, S., Mikić, H. (2006): Kreativne industrije u Srbiji, Beograd: British Council.

- Kvaščev, R. (1976): Psihologija stvaralaštva, Beograd: BIGZ.

- Lubart, T. (2009): Psychologie de la créativité, Paris: Armand Colin.

- Maksić, S. (2015): Darovitost, talenti i kreativnost: od merenja do implicitnih teorija. In G. Maksimović (ed.) (2015): O kreativnosti i umetnosi: savremena psihološka istraživanja (p. 11-29), Niš: Filozofski fakultet Univerziteta.

- Maslov, A. (2001): O životnim vrednostima, Beograd: IP „Žarko Albulj“.

- Maslov, A. (2004): Psihologija u menadžmentu, Novi Sad: Adižes.

- Meng, T.K. (2016): Everyone is born creative, but it is educated out of us at school. Retrieved 16.02.2018 from https://www.theguardian.com/media-network/2016/ may/18/born-creative-educated-out-of-us-school-business.

- Milivojević, T. (2011): Psihologija stvaralaštva, Beograd: Megatrend univerzitet.

- Nascimento, G. (2017): We Are Born Creative Geniuses But The 'Education' System Dumbs Us Down. Retrieved 16.02.2018 from https://anewkindofhuman. com/creative-genius-divergent-thinking-test/.

- Peterson, J. (2003): Low Latent Inhibition Plus High Intelligence Leads To High Creativity?

- Retreived 14.01.2016 from: http://www.futurepundit.com/archives/cat_brain_ creativity.html.

- Radulović, B. Popović, D. Aleksić, D. (2014): Studija o ekonomskom doprinosu industrija zasnovanih na autorskom i srodnim pravima u Republici Srbiji, Privredna komora Srbije, Beograd.

- Ryckman, R.M. (2014): Theories of personality, Belmont: Wadsworth Cengage Learning.

- Roeling, M.P, Willemsen, G, Boomsma, D. (2016): Heritability of Working in a Creative Profession. In Y-M. In Hur (ed.). Behav Genet 47 (3), p.298-304. Retrieved 03.10.2017 from https://link.springer.com/content/ pdf/10.1007\%2Fs10519-016-9832-0.pdf.

- St. Louis I, Lane J. (2016): Start 'Em Up: Incubating Nextgen Innovators, Centre for Human Capital Policy, Canada West Foundation, p.13. Retrived 30.04.2018 from: http://cwf.ca/ wpcontent/uploads/2016/10/HCP_StartEmUpSHAD_ Report_OCT2016_WEB.pdf.

- Winnicott, D. (2005): Playing and Reality (2nd edition), Abingdon: Routledge. 


\section{NEVIDLJIVI I POTCENJENI DOPRINOSI KREATIVNIM POSTIGNUĆIMA}

Kreativnost je visoko cenjena vrednost i sve prisutnija tema u savremenim obrazovnim, ekonomskim, političkim i medijskim diskursima. Smatra se ne samo dragocenim individualnim kvalitetom, već $i$ važnim konkurentskim adutom kompanija i država. $U$ današnje vreme se posebna pažnja pridaje kreativnim industrijama, jer one jačaju nacionalne ekonomije. Ukratko, okruženi smo pozivanjem na kreativnost.

Međutim, isticanje i promovisanje kreativnosti i hvaljenje kreativnh talenata može sakriti našem pogledu sve „nekreativne“ ljudske, materijalne i nematerijalne faktore $i$ resurse koji podržavaju i omogućavaju kreativna ostvarenja. Drugim rečima, iza svakog individualnog ili grupnog kreativnog postignuća stoje oni koji pružaju logističku, organizacionu, finansijsku, istraživačku, društvenu, psihološku i druge vrste podrške. Pojedinci ili timovi ne bi bili sposobni da razviju i realizuju svoje inovativne ideje i projekte bez nekoliko ili više saradnika čiji su raznovrsni talenti, veštine, kompetencije i rad utkani u kreativne procese i rezultate.

Cilj ovog članka nije da umanji izuzetan značaj kreativnosti kao posebnog unutrašnjeg kvaliteta, već da ponudi obuhvatniji pristup njenom manifestovanju, realizovanju $i$ ishodima. Želimo da iznesemo na svetlo dana $i$ odamo priznanje nevidljivim $i$ potcenjenim doprinosima kreativnim aktivnostima. Iako je dobro ohrabrivati $i$ promovisati kreativnost svim raspoloživim sredstvima, trebalo bi izbeći da se ona pretvori u neki novi imperativ, pritisak na sve i svakoga da pokaže svoje kreativne sposobnosti, naročito $u$ obrazovnom polju. Takav stav bi mogao da izazove osećanja frustracije, nedostatka $i$ samoobezvredivanja kod osoba koje nisu naročito kreativne, ali poseduju druge dragocene $i$ korisne kvalitete $i$ veštine, kao što su analitička, logička, praktična, organizaciona, administrativna, menadžerska i druge.

Kreativna postignuća kao rezultati visoko kooperativnih procesa biće ilustrovana primerom kreativnih industrija.

Ključne reči: kreativnost, kooperativni proces, raznovrsni doprinosi, obrazovanje, kreativne industrije. 